\title{
Influenza: Critique of the contemporary challenges for pandemic planning, prevention, control, and treatment in emergency health services
}

\author{
Jennifer R. Patrick, RN RM GradCertCritCare(ICU) MAP (InfPrev\&Cont) ${ }^{a}$, \\ Ramon Z. Shaban, RN IPN CICP EMT-P BSc(Med) BN DipAppSc(Amb) GCInfCon \\ PGDipPH\&TM MEd MCHlth(Hons) FRCNA ${ }^{a, *}$, Gerry FitzGerald, MD, FACEM, \\ FRACMA $^{\mathrm{b}}$
}

a Griffith Health Institute, Research Centre for Clinical and Community Practice Innovation, Griffith University, University Drive, Meadowbrook, QLD 4131, Australia

b School of Public Health, Queensland University of Technology, Victoria Park Road, Kelvin Grove, QLD 4059, Australia

Received 5 January 2011; received in revised form 2 March 2011; accepted 7 March 2011

\section{KEYWORDS \\ Pandemics; \\ Influenza; \\ Planning; \\ Prevention; \\ Control; \\ Treatment; \\ Emergency}

\begin{abstract}
Summary The $2009 \mathrm{H}_{1} \mathrm{~N}_{1}$ influenza pandemic was a major challenge to health services around the world. Previous experiences with Severe Acute Respiratory Syndrome (SARS) and Avian Influenza A (H5N1) prompted initiation of formal pandemic planning. Essential and desirable features of pandemic plans include preparation for surveillance, investigation of cases, treatment modalities, prevention of community spread, maintenance of essential services, research and evaluation, and implementation, testing and revision of the plan.

The experience of $2009 \mathrm{H}_{1} \mathrm{~N}_{1}$ influenza pandemic for emergency departments and their staff was problematic. The pace of the pandemic, coupled with untested pandemic plans, presented a unique range of challenges. In this paper, the contemporary challenges with respect to pandemic influenza prevention, control, and treatment are examined. The lessons learned are critical to our response to future pandemics, which are inevitable.

(c) 2011 College of Emergency Nursing Australasia Ltd. Published by Elsevier Ltd. All rights reserved.
\end{abstract}

\section{Introduction}

The experience with Severe Acute Respiratory Syndrome (SARS) and Avian Influenza A $\left(\mathrm{H}_{5} \mathrm{~N}_{1}\right)$, as well as knowledge of influenza pandemics last century, prompted initiation of formal pandemic planning. Pandemics evolve rapidly, and are

\footnotetext{
* Corresponding author. Tel.: +61 73382 1271/1162; fax: +6173382 1277 .

E-mail address: r.shaban@griffith.edu.au (R.Z. Shaban).
}

1574-6267/\$ - see front matter @ 2011 College of Emergency Nursing Australasia Ltd. Published by Elsevier Ltd. All rights reserved. doi:10.1016/j.aenj.2011.03.001 
complex and unpredictable. In 2004, after the SARS experience, the World Health Organization (WHO) identified the essential and desirable features of pandemic plans, which included: (i) preparation for surveillance; (ii) investigation of cases; (iii) treatment modalities; (iv) prevention of community spread; (v) maintenance of essential services; (vi) research and evaluation, and implementation; and (vii) testing and revision of the plan. ${ }^{1}$ This paper will critique the current literature with respect to contemporary challenges for pandemic influenza prevention, control and treatment.

\section{Defining pandemic influenza}

\section{What is influenza?}

Influenza viruses are myxoviruses, with three main genera, Influenza A, B and C, which are capable of causing infection in humans. ${ }^{2,3}$ Only Influenza A causes epidemics or pandemics in humans. ${ }^{3,4}$ One antigen (haemagglutinin or $\mathrm{H}$ ) on the outer coat of the virus anchors the virus to cells, and another (neuraminidase or $\mathrm{N}$ ) helps it both enter and exit cells. Influenza A subtypes are named according to which subtypes of $\mathrm{H}$ and $\mathrm{N}$ they possess. These antigens alter over time by a process of drift, or repeated minor mutations that occur over time, or shift, or major change in the antigens, which occurs when two different influenza viruses are simultaneously in a host and recombine. ${ }^{2-5}$

Influenza may be transmitted by aerosols, large droplets, and direct and indirect contact. ${ }^{6}$ The relative importance of these modes is considered debatable. ${ }^{7}$ The virus can survive on non-porous surfaces for up to $48 \mathrm{~h}$ and on unwashed hands for 30 min. ${ }^{8}$ Both seasonal and Pandemic $\mathrm{H}_{1} \mathrm{~N}_{1}$ Influenza 2009 outbreaks failed to demonstrate significant airborne transmission over long distances, but aerosol transmission may occur in confined spaces, especially when a large airborne infectious burden is present. ${ }^{7,9}$

\section{What is pandemic influenza, and what is the difference between it and seasonal influenza}

The WHO and the Department of Health and Ageing (DoHA) state an epidemic occurs when there are more cases of a disease than is normal and a pandemic is declared when a worldwide epidemic occurs. ${ }^{10,11}$ The WHO monitors influenza globally and is the body that declares the commencement and end of pandemics. ${ }^{11}$ Influenza pandemics occur when a virus to which people have little or no immunity develops, and efficient human-to-human transmission exists. ${ }^{2,3}$ Pandemics may persist for months, years or decades, have rapid transmission, disease occurrence is outside usual seasonal patterns, and attack and mortality rates across age groups are unpredictable. ${ }^{4}$ The declaration of a 'pandemic influenza' has major effects on resource allocation within government and non-government health agencies. It also has profound effects in the function of societies, including disruption and closure of schools and workplaces, as well as restrictions on travel and social gatherings.

However, the criteria by which an outbreak of an infectious disease may be declared a pandemic are neither fixed nor well defined. ${ }^{12,13}$ They depend on a variety of factors including the relative incidence of an outbreak across jurisdictions, the severity of the infection, and cross-border or transnational cooperation with respect to the epidemiology of the disease. If a pandemic is defined merely by the spread of a new influenza virus strain around the world, the effects of having the formal declaration in place may disproportionately affect the function of society in the event of a mild illness. Criteria also need to be developed for declaring a pandemic 'over'. In the case of Pandemic $\mathrm{H}_{1} \mathrm{~N}_{1} 2009$, countries around the world ceased epidemiological tracking of the infection when it became ubiquitous. Thus there is a need to establish international consensus on the formal definition and criteria for pandemic influenza to allow appropriate response to an outbreak, and to determine when declarations of pandemic may be lifted.

\section{Contemporary challenges}

\section{Pandemic planning}

Pandemic plans require large-scale surge capacity in healthcare systems and the community. Surge capacity is the ability to manage a sudden, unexpected increase in patient volume (i.e., numbers of patients) that would otherwise severely challenge or exceed the current capacity. ${ }^{14}$ Pandemics have health, economic, political, and social impacts. ${ }^{15,16}$ Internationally, healthcare systems have few surplus resources. A 2007 US study identified that regardless of planning, few health services had staff, equipment, and facilities to implement them. ${ }^{17}$ There is no reason to believe that Australia was in any better case.

In Australia, DoHA developed the Australian Health Management Plan for Pandemic Influenza (AHMPPI) ${ }^{18}$ which was tested though Exercise Cumpston in $2006^{19}$ and Exercise Sustain in 2008. ${ }^{15}$ Australian jurisdictional plans complement and augment the AHMPPI. ${ }^{20-28}$ Exercise Cumpston $06^{19}$ gave recommendations on the AHMPPI. These included calling for streamlined decision making processes, flexible response according to disease severity and local resources, improved communications, public health education, a national surveillance framework, clarification of quarantine, border control, and emergency legislation, and involvement of primary care providers in planning. ${ }^{19}$ Two years later, Exercise Sustain $08^{15}$ identified the differences between pandemic and disaster responses, and stressed the impossibility to plan for all eventualities given the unpredictability of new viruses. It addressed local community empowerment, recommending planning with community leaders and groups. Social distancing was identified as an important prevention strategy. Development of a productive relationship between the media and public health agencies, with an emphasis on timeliness, transparency, and honesty was explored, with health professionals considered to have most credibility for message delivery.

Australian state and territory pandemic plans additionally recommend the establishment of flu clinics, separate influenza triage, and designated 'Flu Hospitals' to facilitate quarantine and allow EDs and general practitioners to maintain their core business. These plans aimed for staff protection, including priority vaccination for at-risk staff, pre- and post-exposure prophylaxis, the use of personal 
protective equipment and access to pandemic stockpiles, with those exposed or ill expected to self-isolate. ${ }^{20-28}$ Other identified needs include extra funding, pre-defined triggers for plan implementation and deactivation, anticipatory training of key personnel ${ }^{29}$ and suspension of non-essential and/or non-emergency hospital functions during the crisis. ${ }^{14}$ Ventilators, medications and personal protective equipment were to be stockpiled. Increased cleaning, security and crowd management capacity was identified in the plans, along with the need to increase morgue and laboratory capacity. More non-medical staff are required for administration, communication, transportation, security, cleaning and garbage disposal, and for crowd control. Surge capacity applies across the entire community, with health, government and community groups required to act cooperatively. When individual hospitals reach capacity they need to have means to move patients and/or services to other hospitals or centres. ${ }^{29-31}$ Healthcare worker illness needs to be planned for with use of agency, retired staff, and volunteers. ${ }^{14}$ Seasonal influenza seasons have highlighted a lack of surge capacity in emergency departments (EDs). ${ }^{32}$ The literature shows that pandemic planning and management are complex, expensive and difficult.

In spite of Exercises Cumpston 06 and Sustain 08, Australian pandemic plans were criticised during the $\mathrm{H}_{1} \mathrm{~N}_{1}$ influenza 2009 pandemic for most of the reasons identified as problematic during those exercises. ${ }^{33-35}$ Remedying these problems goes beyond their recognition, and requires sustained and systematic investment on the part of government, the health system, health professionals, and the general public.

\section{Prevention}

Overwhelming evidence exists that it is not possible to prevent pandemics, and when they occur they can cause substantial morbidity, mortality and social disruption. ${ }^{1,36}$ When the $2009 \mathrm{H}_{1} \mathrm{~N}_{1}$ influenza isolate was identified in Mexico, their borders were closed at great economic cost to the country. ${ }^{37}$ However, the virus had already spread. Air travel allows rapid and efficient spread during the incubation period when people are asymptomatic, rendering border closure and controls such as thermal scanning inefficient as a means of prevention. ${ }^{38}$

Surveillance, identifying the onset, nature and size of the outbreak and populations affected is fundamental to pandemic control, identifying spread and trends, determining at-risk populations, allowing for targeted interventions, and monitoring of their effectiveness. ${ }^{38}$ Surveillance of influenza-like illness (ILI) in Mexico allowed for identification and early warning of Pandemic $\mathrm{H}_{1} \mathrm{~N}_{1}$ Influenza 2009, ${ }^{39}$ although there can be little doubt that the virus was circulating for some months prior to formal identification. ${ }^{40}$

\section{Identification}

It is difficult to clinically differentiate patients with influenza from those with other viral respiratory infections. $^{41}$ Rapid antigen point-of-care testing, was shown to have low accuracy for known Pandemic $\mathrm{H}_{1} \mathrm{~N}_{1}$ Influenza 2009, ${ }^{42}$ and reverse transcriptase polymerase chain reaction (RT-PCR) provided the best method of testing. ${ }^{43}$ Obligatory testing of all with respiratory disease ceased during the SUSTAIN phase of the pandemic, as positive diagnosis would not change treatment or isolation, and it would have been a pointless expense to keep testing. ${ }^{34}$ The literature shows testing was problematic and expensive.

\section{Control}

\section{Standard and transmission-based precautions}

Immunisation is a primary tool for pandemic influenza control, however it takes time to develop and manufacture vaccines. ${ }^{16,29}$ In the interim, community mitigation strategies including social distancing, cough and sneeze etiquette, and frequent thorough hand hygiene may be used. ${ }^{29,38}$ Atrisk groups need targeted information and intervention. ${ }^{38}$ Contact tracing of healthcare worker and patients' contacts has been recommended to identify those with risk factors for severe disease who may benefit from antiviral prophylaxis. ${ }^{7}$

A recent study in Australia of the knowledge and attitudes the general public held towards Pandemic $\mathrm{H}_{1} \mathrm{~N}_{1}$ Influenza $2009^{44}$ found low levels of public anxiety, a high degree of belief in government preparedness, vaccination and quarantine as effective public health measures, antiviral medication as moderately effective, and a low level of belief in hand hygiene as a preventative measure. Quarantine was cited as being problematic with respect to work and food shopping. The literature shows that hand hygiene education and vaccination development are required for pandemic influenza control.

Social distancing is effective in infection control as a form of isolation. At the commencement of the 2009 pandemic, health department officials advised people with ILI to present to their local ED ${ }^{45}$ causing overwhelming presentations by those with ILI and those fearful they may have had contact. ${ }^{34,46,47}$ In a pandemic, general practitioner and hospital waiting rooms are a potential site for cross infection to already unwell people if people present with a highly infectious illness. This happened during the SARS outbreak in Canada in 2003. ${ }^{48}$ The literature indicates that these patients are best treated in other sites. Overcrowded living conditions contribute to rapid influenza spread. ${ }^{16}$ This contributed to the disproportionately high impact of Pandemic $\mathrm{H}_{1} \mathrm{~N}_{1}$ Influenza 2009 in indigenous communities in the Northern Territory. ${ }^{49}$ School closures have been used as a means of social distancing. However a Western Australian survey of parents whose children were in schools closed during the $\mathrm{H}_{1} \mathrm{~N}_{1}$ influenza 2009 pandemic ${ }^{50}$ revealing that $74 \%$ of these students participated in out of home activities including sporting events, shopping, outdoor recreation and parties while their schools were closed. This paper questions the efficacy of school closure in preventing infection spread, highlighting that students were congregating elsewhere.

An example of effective isolation practice was seen during the simultaneous outbreak of Pandemic $\mathrm{H}_{1} \mathrm{~N}_{1}$ Influenza 2009 and seasonal $\left(\mathrm{H}_{3} \mathrm{~N}_{2}\right)$ influenza which was contained on two Australian cruise ships. ${ }^{51}$ The conditions encouraging contagion on the ships included living and socialising in partially enclosed close proximity, and people from both 
hemispheres (i.e., opposite flu season) coming together. Prior to the outbreak, the ship procedures already included point-of-care testing, antiviral medication and isolation for ILI patients. However, not all ill passengers sought medical care, presumably because they had mild illness or were unwilling to be isolated while holidaying. After disembarkation, passengers discovered their need to be quarantined via media reports, word of mouth, from ship staff or public heath staff. Almost all complied with quarantine requirements, and only one case of infection passed from a passenger to another person was found, with no further community spread. Thus, an epidemic on board ships was prevented from contributing to the 2009 Pandemic.

Many people continue to work when they are ill. In the tropics influenza is under-recognised and under-diagnosed, which can cause people to inadvertently infect families, colleagues and patients. ${ }^{52}$ Studies have shown that many healthcare workers either go to work or intend to work when they have influenza. ${ }^{53-55}$ One hospital in the USA experienced high levels of infection in their EDs at the peak of $\mathrm{H}_{1} \mathrm{~N}_{1}$ influenza 2009 pandemic, with no commensurate increase in sick leave. ${ }^{56}$ This finding was reflected in a recent Australian study. ${ }^{34}$ Thus, the literature indicates that healthcare workers need further education on this matter.

Australian healthcare guidelines recommend contact and droplet precautions for influenza control. ${ }^{57}$ Contact precautions include surface cleaning, hand hygiene, the use of gloves and gowns, single-use equipment wherever possible, and masks and eye protection when splashes may occur. Additionally, droplet precautions add patient isolation or cohorting and minimising patient transfers. Particulate respirators, eye protection, and impervious gowns and gloves, are advised for all aerosol-generating procedures, which should be performed in a negative pressure room if available. ${ }^{7,41,58,59}$ Australian guidelines recommend surgical masks for those entering an infectious area, coming within $1 \mathrm{~m}^{57}$ or $2 \mathrm{~m}^{7}$ of an infectious patient. Where tolerated, masking the patient is more effective than masking the health care workers. ${ }^{60}$ Personal protective equipment is vital to healthcare workers who cannot be protected in any other way prior to effective vaccine development. In 2009, slow distribution of personal protective equipment from the national stockpile to frontline workers was a problem, with general practitoner practices running out of stock and being unable to replace it early in the pandemic. ${ }^{35}$

While the CDC recommends the use of respiratory protection of at least the equivalent of $\mathrm{N} 95$ masks $^{61}$ for health care workers managing patients with ILI, Canadian research has found N95 masks are no more protective in influenza than normal surgical masks. ${ }^{62}$ Inconsistencies in recommendations between authorities must be resolved to improve staff compliance and confidence. ${ }^{63}$ Thus the literature calls for better distribution of personal protective equipment during an influenza pandemic and identifies research is required into appropriate mask usage.

\section{Education and information}

Public education is vital to stop influenza spread. Materials used must target the audience and be culturally appropriate. In the Hunter New England area, focus groups identified challenges and potential solutions for limiting pandemic influenza in indigenous communities. ${ }^{64}$ These included having a local resource person with an understanding of the disease, provision of clear, simple, culturally appropriate information, access to health services and knowledge of how obtain these without infecting others, sensitivity to the importance of family and cultural gatherings, and Aboriginal people having a say in how support is provided. Pregnant women were targeted and encouraged to take precautions against acquiring infection and accept vaccination. ${ }^{65}$ DoHA developed a website ${ }^{10}$ which gave detailed advice for individuals, households, healthcare providers, businesses and communities, and provided a telephone hotline. This allowed people to receive the best possible advice in a timely fashion.

The media are vital to spreading public health messages, but can be sensationalist, ill-informed, and may desensitise the public to the issue through information overload or precipitate 'moral panic'. ${ }^{34,38}$ A single, knowledgeable, authoritative voice has the best chance of conveying information effectively. ${ }^{34}$

\section{Vaccination}

While vaccination is vital to halt the spread of pandemics, time is needed for development and production. ${ }^{38}$ An American study found that most of the people they surveyed would not accept a new, not fully tested vaccine approved under Emergency Use Authorization. ${ }^{66}$ Healthcare worker immunisation rates in Australia are reportedly between $20 \%$ and $50 \%{ }^{67}$ Reasons include low perception of personal risk, poor knowledge of how immunisation works, doubts about vaccine efficacy and/or safety, self-perceived contraindications, and inconvenient access. ${ }^{68}$ In spite of the Hong Kong experience of SARS, a study conducted prior to and repeated during the outbreak of Pandemic $\mathrm{H}_{1} \mathrm{~N}_{1}$ Influenza 2009 reported no significant increase in intention to receive immunisation, with participants citing fears of side effects and doubts of efficacy. ${ }^{69}$ This was echoed in a more recent Australian study ${ }^{34}$ with widespread perception that the Pandemic $\mathrm{H}_{1} \mathrm{~N}_{1}$ Influenza 2009 vaccine was rushed into production and not comprehensively tested. ${ }^{34,70}$ Low acceptance was also reported in Greece. ${ }^{71}$ In the USA there was low public willingness to accept vaccination under an emergency order. ${ }^{66}$ When released in Australian, presentation in multi-dose vials posed a problem, with insurance companies initially refusing to cover administering general practitioners. ${ }^{72}$ The use of multi-dose vials for mass immunisation was part of the AHMPPI, and known associated risks can be minimised by adherence to clear guidelines on their use. ${ }^{73}$ Alternative vaccination sites, including retail outlets and workplaces, have been proposed to increase public uptake of influenza vaccination. ${ }^{74}$ British Columbia has proposed regulatory changes to allow pharmacists to administer vaccines. $^{75}$

\section{Treatment}

Treatment for pandemic influenza is a matter of conjecture until the actual virus is identified and the clinical profile emerges. Most Pandemic $\mathrm{H}_{1} \mathrm{~N}_{1}$ Influenza 2009 cases 
required simple supportive treatment including rest, fluids, and antipyretics, ${ }^{34}$ however advanced oxygenation therapy including high-frequency oscillation ventilation, nitric oxide or extracorporeal membrane oxygenation was required for some with severe disease. Stockpiled ventilators were too old or too simple to provide complex ventilation strategies. ${ }^{76-79}$

Debate occurred about the efficacy of oseltamivir for the treatment and prevention of Pandemic $\mathrm{H}_{1} \mathrm{~N}_{1}$ Influenza 2009. The Cochrane Review concluding it merely shortened the duration of symptoms by $24 \mathrm{~h}$ if given within $48 \mathrm{~h}$ of disease onset, and thus should only be given to those sufferers with known risk factors for severe disease ${ }^{80-82}$ especially as side effects include gastrointestinal symptoms and headaches, with rare cases of delirium and psychosis (most frequently in children and adolescents), raised liver enzymes, and allergic reactions. ${ }^{83}$ Guidelines recommend oseltamivir administration within $48 \mathrm{~h}$ of disease onset. ${ }^{83}$ Adherence to this would have seen many treated for a disease they did not have in the $\mathrm{H}_{1} \mathrm{~N}_{1}$ influenza 2009 pandemic, as overwhelmed pathology services saw extended time lags between specimens being sent for testing and the arrival of results. ${ }^{33}$

\section{Conclusion}

Generally speaking, humanity was better prepared for the $\mathrm{H}_{1} \mathrm{~N}_{1}$ influenza 2009 pandemic than for any other pandemic in history. While the disease itself was less virulent than expected, it confirmed the unpredictability of pandemic influenza, and its ability to cause significant impacts on health systems and the community. The $\mathrm{H}_{1} \mathrm{~N}_{1}$ influenza 2009 pandemic highlighted unresolved challenges identified in both Exercise Cumpston 06 and Exercise Sustain 08, which we as a profession and society must address. Public health challenges include developing means of increasing acceptance of influenza vaccination by both the general public and healthcare workers, provision of targeted education for the indigenous population and other at-risk groups, improving public knowledge of social distancing and personal hygiene measures in the prevention of transmission, and improving dissemination of information during a pandemic, especially via the media. We can use the evidence to refine pandemic plans and promote community well-being during an influenza pandemic.

\section{Provenance and conflicts of interest}

Jennifer R. Patrick and Gerard J. FitzGerald have no competing interests or conflict of interests to declare. Ramon Z. Shaban is Editor-in-Chief of the Australasian Emergency Nursing Journal but had no role in the editorial review of this manuscript whatsoever, and has no other competing interests or conflict of interests to declare.

\section{Funding}

This paper was supported by funding awarded by the National Health and Medical Research Council in 2009 for the following project: Emergency Department impact and patient profile of $\mathrm{H} 1 \mathrm{~N} 1$ Influenza 09 outbreak in Australia: A national survey. (grant number 614290).

\section{References}

1. World Health Organization. WHO checklist for influenza pandemic preparedness planning; 2005. http: / /www.who.int/ entity/csr/resources/publications/influenza/FluCheck6web. pdf [accessed 10th January 2010].

2. Department of Health and Ageing. Pandemic Influenza Types of influenza; 2008. http://www.flupandemic. gov.au/internet/panflu/publishing.nsf/Content/types-1.

3. Lee G, Bishop P. Microbiology and infection control for health professionals. 3rd ed. Pearson Prentice Hall; 2006.

4. Mandell GL, Bennett JE, Dolin R, Mandell. Douglas, and Bennett's principles and practice of infectious diseases, vol. 1 and 2, 7th ed. Philadelphia: Churchill Livingstone; 2009, http://www.mdconsult.com.ezp01.library.qut.edu.au/book/ player/book.do?method=display\&type=aboutPage\&decorator= header\&eid=4-u1.0-B978-0-443-06839-3.X0001-X-TOP\&isbn= 978-0-443-06839-3\&uniq $=193761564$.

5. Watts G. A/H1N1 influenza virus THE BASICS. BMJ 2009;339(7717):368-9.

6. Hawker J, Begg N, Blair I, Reintjes R, Weinberg J. Communicable disease control handbook. 2nd ed. Massachusetts: Blackwell Publishing; 2005.

7. Stuart RL, Cheng AC, Marshall CL, Ferguson JK. ASID (HICSIG) position statement: infection control guidelines for patients with influenza-like illnesses, including pandemic (H1N1) influenza 2009, in Australian health care facilities. eMJA 2009 [Rapid Online Publication - 21 September 2009].

8. Salgado CD, Farr BM, Hall KK, Hayden FG. Influenza in the acute hospital setting. Lancet Infect Dis 2002;2(3):145-55.

9. World Health Organization. Clinical management of human infection with pandemic (H1N1) 2009: revised guidance; 2009. Available at: http://www.who.int/entity/ csr/resources/publications/swineflu/clinical_management_ h1n1.pdf [accessed 24th November 2009].

10. Department of Health and Ageing. Pandemic influenza; 2009. http://www.flupandemic.gov.au/internet/panflu/publishing. nsf/Content/home-1 [accessed 10th October 2010].

11. World Health Organisation. Pandemic preparedness; 2010. http://www.who.int/csr/disease/influenza/pandemic/en/ [accessed 30th October 2010].

12. Collignon P. Swine flu - lessons learnt in Australia. Med J Aust 2010;192:364-5.

13. Doshi P. Calibrated response to emerging infections. BMJ 2009;339:603-5.

14. Hick JL, Hanfling D, Burstein JL, DeAtley C, Barbisch D, Bogdan GM, et al. Health care facility and community strategies for patient care surge capacity. Ann Emerg Med 2004;44(3):253-61.

15. Council of Australian Governments. Working group on Australian influenza pandemic prevention and preparedness. Exercise sustain 08 overview. In: Governments, CoA, editors. Canberra: The Department of the Prime Minister and Cabinet; 2008.

16. World Health Organisation. WHO consultation on priority public health interventions before and during an influenza pandemic; 2005. http://www.who.int/ entity/csr/disease/avian_influenza/consultation/en/index.html [accessed 22nd October 2010].

17. Rebmann T, Wilson R, LaPointe S, Russell B, Moroz D. Hospital infectious disease emergency preparedness: a 2007 survey of infection control professionals. Am J Infect Control 2009;37(1):1-8. 
18. Department of Health and Ageing Office of Health Protection. Australian health management plan for pandemic influenza; 2008. http://www.flupandemic. gov.au/internet/panflu/publishing.nsf/Content/ahmppi.

19. Department of Health and Ageing. National pandemic influenza exercise - exercise Cumpston 06 report. Canberra; 2007.

20. ACT Health. Australian capital territory health management plan for pandemic influenza 2007; 2007. http: //www. health. act.gov. au/c/health?a=sendfile\&ft $=$ p\&fid $=1209009455 \&$ sid $=$.

21. Communicable Disease Control Unit. Victorian health management plan for pandemic influenza; 2007. http: //www. health. vic.gov.au/__data/assets/pdf_file/0017/54503/Victorian_ health_management_plan_for_pandemic_influenza.pdf.

22. Department of Health. Western Australian Health Management Plan for Pandemic Influenza 2009; 2009. http://www.public. health.wa.gov.au/cproot/2233/2/Western\%20Australian \%20Health\%20Management\%20Plan\%20for\%20Pandemic \%20Influenza\%202009.pdf.

23. Department of Health South Australia. Pandemic influenza: a summary of health's operational plan; 2007. http: / /www.pandemicinfluenza.sa.gov.au/LinkClick.aspx? fileticket=H6wF0tzp9x8\%3d\&tabid=61.

24. Northern Territory Counter Disaster Council. Special counter disaster plan: human pandemic influenza; 2006. http://www.health.nt.gov.au/library/scripts/objectifyMedia. aspx?file=pdf $/ 31 / 59$.pdf\&sitelD=1\&str_title=NT\%20Special\%20 Counter\%20Disaster\%20Plan\%20for\%20Human\%20Pandemic\%20 Influenza.pdf.

25. NSW Health. Hospital response to pandemic influenza, part 1: Emergency Department response; 2007. http://www. health.nsw.gov.au/policies/pd/2007/pdf/PD2007_048.pdf.

26. NSW Health. NSW Human Influenza Pandemic Sub Plan; 2008. http://www.emergency.nsw.gov.au/content.php/583. html.

27. Queensland Department of the Premier and Cabinet. Queensland pandemic influenza plan 2009; 2009. http://www.premiers.qld.gov.au/publications/categories/ plans/assets/ pandemic-influenza-plan-2009.pdf.

28. Tasmanian Pandemic Influenza Project. Tasmanian action plan for human influenza pandemic; 2008. http:// www.pandemic.tas.gov.au/_data/assets/pdf_file/0016/61801/ Tasmanian_Action_Plan_for_Human_Influenza.pdf.

29. Runge JW, Almeida S-L, Bern Al, Bitterman RA, Bogucki $\mathrm{S}$, Brennan JA, et al. National strategic plan for emergency department management of outbreaks of novel H1N1 influenza. American College of Emergency Physicians; 2009.

30. Bonnett CJ, Peery BN, Cantrill SV, Pons PT, Haukoos JS, McVaney KE, et al. Surge capacity: a proposed conceptual framework. Am J Emerg Med 2007;25(3):297-306.

31. Itzwerth RL, Maclntyre CR, Shah S, Plant AJ. Pandemic influenza and critical infrastructure dependencies: possible impact on hospitals. MJA 2006;185(10):s70-2.

32. McKenna $M$, Vaccine Mishap. Flu outbreak overwhelm EDs highlight lack of surge capacity. Ann Emerg Med 2008;51(6):739-41.

33. Grayson ML, Johnson PD. Australia's influenza containment plan and the swine flu epidemic in Victoria. MJA 2009; 191(3).

34. FitzGerald G, Patrick J, Fielding E, Shaban R, Arbon P, Aitken P, et al. Pandemic (H1N1) 2009 influenza outbreak in Australia: impact on emergency departments. Brisbane, Australia: Queensland University of Technology; 2010.

35. Eizenberg P. The general practice experience of the swine flu epidemic in Victoria - lessons from the front line. Med J Aust 2009;191 (August (3)):151-3.

36. Gensheimer KF. Challenges and opportunities in pandemic influenza planning: lessons learned from recent infectious disease preparedness and response efforts. Int Cong Ser 2004; 1263:809-12.

37. Stern AM, Markel H. What Mexico taught the world about pandemic influenza preparedness and community mitigation strategies. JAMA 2009;302(September (11)):1221-2.

38. Plant AJ, Watson C. Communicable disease control an introdction. Melbourne: IP Communications; 2008.

39. World Health Organization. New influenza $A(H 1 N 1)$ virus infections: global surveillance summary. Wkly Epidemiol Rec 2009;84(May (20)):173-9.

40. Kelly HA, Mercer GN, Fielding JE, Dowse GK, Glass K, Carcione D, et al. Pandemic (H1N1) 2009 influenza community transmission was established in one Australian state when the virus was first identified in North America. PLoS ONE 2010;5(6):e11341.

41. Cheng AC, Dwyer DE, Kotsimbos AT, Starr M, Korman TM, Buttery JP, et al. Summary of the Australasian Society for Infectious Diseases and the Thoracic Society of Australia and New Zealand guidelines: treatment and prevention of H1N1 influenza 09 (human swine influenza) with antiviral agents. Med $J$ Aust 2009;191(August (3)):142-5.

42. Drexler JF, Helmer A, Kirberg H, Reber U, Panning M, Müller M, et al. Poor clinical sensitivity of rapid antigen test for influenza A pandemic (H1N1) 2009 virus. Emerg Infect Dis 2009; (October) [Epub ahead of print].

43. Panning $M$, Eichmann $M$, Landt $O$, Monazahian $M$, Ölschläger $S$, Baumgarte $S$, et al. Detection of influenza $A(\mathrm{H} 1 \mathrm{~N} 1) \mathrm{V}$ virus by real-time RT-PCR. Euro Surveill 2009;14(36) [pii = 19329].

44. Seale H, McLaws M-L, Heywood AE, Ward KF, Lowbridge CP, Van $D$, et al. The community's attitude towards swine flu and pandemic influenza. eMJA 2009;(29 July), http://www. mja.com.au/public/issues/191_05_070909/sea10770_fm.html.

45. Shaban R. H1N1 Influenza 09-managing the 'moral panic'. Aust Emerg Nurs J 2009;12(3):69-70.

46. Medew J, Smith B. Hospitals inundated as swine flu panic spreads. Age 2009; (May).

47. Neergaard L. Flu planners fear ERs flooded with the not-so-sick; 10 August 2009.

48. Borgundvaag B, Ovens $H$, Goldman B, Schull M, Rutledge T, Boutis $\mathrm{K}$, et al. SARS outbreak in the Greater Toronto Area: the emergency department experience. Can Med Assoc J 2004;171(11):1342 [Ottawa].

49. Flint SM, Davis JS, Su J-Y, Oliver-Landry EP, Rogers BA, Goldstein A, et al. Disproportionate impact of pandemic (H1N1) 2009 influenza on indigenous people in the top end of Australia's northern territory. Med J Aust 2010;192(10):617-22.

50. Effler PV, Carcione D, Dowse GK, Goggin L, Mak DB. Household responses to pandemic (H1N1) 2009-related school closures, Perth, Western Australia. Emerg Infect Dis 2010;(February) [Epub ahead of print].

51. Ward KA, Armstrong P, MCAnulty JM, Iwasenko JM, Dwyer DE. Outbreaks of pandemic (H1N1) 2009 and seasonal influenza A (H3N2) on cruise ship. Emerg Infect Dis 2010;16(11) [serial on the Internet].

52. Leo Y-S, Lye DC, Chow A. Influenza in the tropics. Lancet Infect Diss 2009;9(8):457-8.

53. Brown LH, Aitken P, Leggat PA, Speare R. Self-reported anticipated compliance with physician advice to stay home during pandemic (H1N1) 2009 results from the 2009 Queensland Social Survey. BMC Public Health 2010;10:138.

54. Elder AG, O'Donnell B, MCCruden EA, Symington IS, Carman WF. Incidence and recall of influenza in a cohort of Glasgow healthcare workers during the 1993-4 epidemic: results of serum testing and questionnaire. BMJ 1996;313(November (7067)):1241-2.

55. Seale H, Leask J, Po K, MacIntyre CR. "Will they just pack up and leave?" - attitudes and intended behaviour of hospital health care workers during an influenza pandemic. BMC Health Serv Res 2009;9:30. 
56. Santos CD, Bristow RB, Vorenkamp JV. Which health care workers were most affected during the spring $2009 \mathrm{H} 1 \mathrm{~N} 1$ pandemic? Disaster Med Public Health Prep 2010;4(March (1)):47-54.

57. National Health Medical Research Council. Australian guidelines for the prevention and control of infection in healthcare. Canberra: Commonwealth of Australia; 2010.

58. Centers for Disease Control \& Prevention. Interim guidance on infection control measures for 2009 H1N1 influenza in healthcare settings, including protection of healthcare personnel; 2009. http://www.cdc.gov/h1n1flu/guidelines_infection_control.htm. [accessed 19th January 2010].

59. World Health Organization. Infection prevention and control in health care for confirmed or suspected cases of pandemic (H1N1) 2009 and influenza-like illnesses; 2009. http://www.who.int/entity/csr/resources/publications/ cp150_2009_1612_ipc_interim_guidance_h1n1.pdf [accessed 27th January 2010].

60. Mermel LA. Preventing the spread of influenza A H1N1 2009 to health-care workers. Lancet Infect Dis 2010;9(12): 723-4.

61. Centers for Disease Control Prevention. Outbreak of swineorigin influenza A (H1N1) virus infection - Mexico, March-April 2009. MMWR Morb Mortal Wkly Rep 2009;58(May (17)):467-70.

62. Loeb M, Dafoe N, Mahony J, John M, Sarabia A, Glavin V, et al. Surgical mask vs $N 95$ respirator for preventing influenza among health care workers: a randomized trial. JAMA 2009;302(17).

63. Hanfling D, Hick JL. Hospitals and the Novel H1N1 outbreak: the mouse that roared? Disaster Med Public Health Prep 2009;3(Suppl. (2)):1-7.

64. Massey PD, Pearce G, Taylor KA, Orcher L, Saggers S, Durrheim DN. Reducing the risk of pandemic influenza in Aboriginal communities. Rural Remote Health 2009;9(1290).

65. Centers for Disease Control \& Prevention. Pregnant women need a flu shot; 2010. http://www.cdc. gov/features/PregnancyAndFlu/ [accessed 26th October 2010.].

66. Quinn SC, Kumar S, Freimuth VS, Kidwell K, Musa D. Public willingness to take a vaccine or drug under emergency use authorization during the $2009 \mathrm{H} 1 \mathrm{~N} 1$ pandemic. Biosecur Bioterrorism, Biodefense Strategy Pract Sci 2009;7(3):275-90.

67. Influenza Specialists Group. Influenza vaccination among healthcare workers; 2006. http://www.influenzacentre. org/reports/hcw5_06.pdf, 2010.

68. Hollmeyer HG, Hayden F, Poland G, Buchholz U. Influenza vaccination of health care workers in hospitals - a review of studies on attitudes and predictors. Vaccine 2009;27(30):3935-44.
69. Chor JSY, Ngai KL, Goggins WB, Wong MCS, Wong SYS, Lee N, et al. Willingness of Hong Kong healthcare workers to accept pre-pandemic influenza vaccination at different WHO alert levels: two questionnaire surveys. BMJ 2009;339(252):b3391.

70. Neale T. Toll of second swine flu wave could be high. MedPage Today 2009.

71. Rachiotis G, Mouchtouri V, Kremastinou J, Gourgoulianis K, Hadjichristodoulou C. Low acceptance of vaccination against the 2009 pandemic influenza $\mathrm{A}(\mathrm{H} 1 \mathrm{~N} 1)$ among healthcare workers in Greece. Euro Surveill 2010;15(6).

72. Herbert $B$, Lane $S$. Insurance row threatens swine flu vaccinations. $A B C$ News 2009; (August).

73. Gardner A. H1N1 and the use of multi-dose vials in mass vaccination. Aust Nurs J 2009;17(October (4)):13.

74. Lee BY, Mehrotra A, Burns RM, Harris KM. Alternative vaccination locations: who uses them and can they increase flu vaccination rates? Vaccine 2009;27(32):4252-6.

75. Ministry of Health Services British Columbia. Proposed changes allow pharmacists to give injections. In: Columbia MoHSB, editors. 21st July ed. Victoria; 2009.

76. Corley A, Hammond NE, Fraser JF. The experiences of health care workers employed in an Australian intensive care unit during the H1N1 Influenza pandemic of 2009: A phenomenological study. Int J Nurs Stud 2010;47(5):577-85.

77. Eggerston L. Critical care doctors want escalated pandemic planning. CMAJ 2009;181(September (5)):253-4.

78. Sandrock C. Novel H1N1 influenza: the impact on respiratory disease and the larger healthcare system. Expert Rev Respir Med 2009;3(4):335-8.

79. Hebert PC, MacDonald N. Preparing for pandemic (H1N1) 2009. CMAJ 2009; 181 (September (6-7)):E102-103.

80. Doshi P. Neuraminidase inhibitors-the story behind the Cochrane review. BMJ 2009 December 9;339 [(dec07_2):b5164].

81. Freemantle $N$, Calvert $M$. What can we learn from observational studies of oseltamivir to treat influenza in healthy adults? BMJ 2009;339(December) [(dec07_2):b5248].

82. Jefferson $T$, Jones $M$, Doshi $P$, Del Mar C. Neuraminidase inhibitors for preventing and treating influenza in healthy adults: systematic review and meta-analysis. BMJ 2009 December 8;339 [(dec07_2):b5106].

83. MIMS Online. Mims Australia; 2010. https://www.mimsonlinecom-au.libraryproxy.griffith.edu.au/Search/FullPI.aspx?Module Name=Product\%20Info\&searchKeyword=Oseltamivir+phosphate \&PreviousPage $=\sim /$ Search $/$ QuickSearch. aspx\&SearchType=\&ID=55420001_2\#an-AdverseReactions 5230 [accessed 19th April 2010]. 